Syntax Literate: Jurnal Ilmiah Indonesia p-ISSN: 2541-0849

e-ISSN: 2548-1398

Vol. 6, No. 2, Februari 2021

\title{
PENGARUH DIVIDEND PAYOUT RATIO DAN DEBT TO EQUITY RATIO TERHADAP PRICE EARNINGS RATIO
}

\section{Janiman}

Universitas Swadaya Gunung Djati

Email: janimancrb@gmail.com

\begin{abstract}
This study aims to find out and analyze the effect of dividend payout ratio and debt to equity ratio on price earnings ratio. This type of research uses basic research with causality research method. The population in this study is all real estate and building contructions sector companies listed on the indonesia stock exchange in 2016-2018. The determination of samples is done by purposive sampling techniques that are determined based on certain criteria and obtained 60 company sample data. The data used in this study is secondary data obtained from the company's financial statements data that has been published through the www.idx.co.id. The study used multiple linear regression analysis and classic assumption tests that included normality tests, multicolinearity tests, heterosesedastisity tests, and autocorrelation tests. Hypothesis test is done through partial test ( $t$ test) and coefficient of determination test. Testing is done using SPSS 25 software tools for windows. The results showed that dividend payout ratio affects price earnings ratio and debt to equity ratio has no effect on price earnings ratio.
\end{abstract}

Keywords: rasio pembayaran dividen; rasio utang terhadap ekuitas; rasio penghasilan harga

\begin{abstract}
Penelitian ini bertujuan untuk mengetahui dan menganalisis pengaruh dividend payout ratio dan debt to equity ratio terhadap price earnings ratio. Jenis penelitian ini menggunakan penelitian dasar dengan metode penelitian kausalitas. Populasi dalam penelitian ini adalah seluruh perusahaan sektor property real estate and building contructions yang terdaftar di bursa efek indonesia pada tahun 2016- 2018. Penentuan sampel dilakukan dengan teknik purposive sampling yang ditetapkan berdasarkan kriteria tertentu dan diperoleh 60 data sampel perusahaan. Data yang digunakan dalam penelitian ini adalah berupa data sekunder yang diperoleh dari data laporan keuangan perusahaan yang telah dipublikasikan melalui situs www.idx.co.id. Penelitian ini menggunakan analisis regresi linear berganda dan uji asumsi klasik yang meliputi uji normalitas, uji multikolinearitas, uji heteroskedastisitas, dan uji autokorelasi. Uji hipotesis dilakukan melalui uji parsial (uji t) dan uji koefisien determinasi. Pengujian dilakukan dengan menggunakan alat bantu software SPSS 25 for windows. Hasil penelitian menunjukkan bahwa dividend payout ratio berpengaruh terhadap price earnings ratio dan debt to equity ratio tidak berpengaruh terhadap price earnings ratio.
\end{abstract}


Kata Kunci: dividend payout ratio; debt to equity ratio; price earnings ratio

Coresponden Author

Email: janimancrb@gmail.com

Artikel dengan akses terbuka dibawah lisensi

\section{Pendahuluan}

Saham merupakan salah satu jenis instrumen yang diperdagangkan di pasar modal dan menarik untuk diinvestasikan karena saham mempunyai tingkat risiko yang tinggi, tetapi dapat menghasilkan tingkat pengembalian (return) yang tinggi juga. Dikarenakan tingginya risiko dalam berinvestasi saham, maka investor perlu memahami risiko apa saja yang kemungkinan akan terjadi pada saat memutuskan untuk membeli saham karena tidak semua saham yang diperjualbelikan itu mempunyai kinerja yang baik. Maka alangkah baiknya sebelum melakukan pembelian, calon investor diharapkan dapat mengetahui terlebih dahulu mengenai bagaimana hasil dari kinerja perusahaan tersebut.

Secara umum ada dua pendekatan penilaian harga saham untuk megetahui nilai saham yang sebenarnya, yaitu analisis teknikal dan analisis fundamental. Analisis teknikal yaitu untuk investasi jangka pendek, dimana investor membeli saham saat harga saham rendah dan menjualnya kembali pada saat harga saham tinggi sehingga akan mendapatkan keuntungan. Lalu analisis fundamental yaitu dapat didasarkan dari laporan keuangan perusahaan sebagai alat ukur utamanya. Laporan keuangan yang diumumkan perusahaan akan dianalisis terlebih dahulu hasilnya apakah dapat memberikan sinyal yang baik atau buruk jika beriventasi, kemudian informasi tersebut nantinya bisa dijadikan keputusan investasi untuk para investor.

Harga saham dapat mempengaruhi penawaran dan permintaan di pasar modal, apabila dinilai terlalu tinggi maka jumlah permintaannya akan berkurang (Rusliati \& Farida, 2010). Perlu diketahui bahwa harga dari suatu saham bergantung pada tingkat permintaan dan penawaran yang terjadi di bursa sehingga harga tersebut dapat berubahubah. Besarnya tingkat permintaan dan penawaran suatu saham dapat dipengaruhi oleh ketertarikan investor terhadap informasi yang telah dipublikasikan perusahaan tersebut sebagai suatu sinyal positif ataupun sinyal negatif. Oleh karena itu investor harus menelusuri tentang faktor-faktor apa saja yang dapat mempengaruhi perubahan harga saham karena harga saham merupakan indikator penting dalam menentukan price earnings ratio, maka setiap perubahan harga yang terjadi akan sangat berpengaruh terhadap nilai price earnings ratio. Indeks Harga Saham Gabungan (IHSG) di Bursa Efek Jakarta beberapa bulan terakhir ini mencatat sejarah baru dengan level-level tertinggi yang pernah dicapainya (Tambunan, 2008). Analisis terhadap penilaian Harga Saham merupakan langkah mendasar yang harus dilakukan sebelum melakukan investasi (Safitri, 2013). 
Berikut disajikan data price earnings ratio industri pada sektor sektor property real estate and building construction yang terdaftar di bursa efek indonesia pada tahun 2016-2018 berdasarkan laporan ringkasan kinerja sebagai berikut:

\section{Tabel 1}

Data rata-rata Price Earnings Ratio Sektor Property Real Estate and Building Construction yang Terdaftar di Bursa Efek Indonesia Tahun 2016-2018

\begin{tabular}{ccc}
\hline \multicolumn{3}{c}{ Price Earning Ratio Industry (kali) } \\
\hline 2016 & 2017 & 2018 \\
\hline 24,89 & 14,52 & 27,07 \\
\hline
\end{tabular}

Sumber: www.idx.co.id

Dari tabel dapat dilihat bahwa price earnings ratio sektor property real estate and building construction pada tahun 2016-2018 mengalami perubahan, ada yang mengalami kenaikan maupun penurunan setiap tahunnya. Pergerakan dari laba bersih per saham dan harga saham mengakibatkan perubahan PER. Pada tabel nilai PER pada tahun 2016 sebesar 24,89 kali sedangkan pada tahun 2017 turun menjadi 14,52 kali dikarenakan harga properti yang mulai mahal sehingga banyak masyarakat yang lebih fokus belanja untuk memenuhi kebutuhan pokok terlebih dahulu, kemudian pada tahun 2018 mengalami peningkatan menjadi sebesar 27,07 kali dikarenakan beberapa perusahaan sektor properti penjualannya mengalami peningkatan sehingga labanya pun mengalami peningkatan.

Investasi ialah penanaman modal yang dilakukan oleh investor (Sudirman \& Alhudhori, 2018). Investor adalah seseorang atau lembaga domestik/non domestik yang melakukan investasi baik dalam jangka pendek atau jangka panjang (Simadibrata, 2012). Investor biasanya lebih tertarik dengan nilai PER yang tinggi karena perusahaan tersebut memiliki prospek pertumbuhan dan memiliki kualitas sehingga pasar menilai saham tersebut dengan harga tinggi dan dengan harapan harga saham juga akan tinggi. Menurut (Hanafi \& Halim, 2016), perusahaan yang diharapkan akan tumbuh tinggi (mempunyai prospek baik) mempunyai PER tinggi, sebaliknya perusahaan yang diharapkan mempunyai pertumbuhan rendah akan mempunyai PER yang rendah. PER yang tinggi menunjukan ekspektasi investor tentang prestasi perusahaan dimasa yang akan datang cukup tinggi (Harahap, 2015). Tinggi rendahnya price earnings ratio mengindikasikan bahwa terdapat faktor-faktor yang mempengaruhinya. Oleh sebab itu penelitian ini bertujuan untuk menganalisis mengenai faktor apa saja yang dapat mempengaruhi price earnings ratio. Dalam penelitian ini faktor yang mempengaruhinya yaitu dividend payout ratio dan debt to equity ratio.

Berbagai penelitian mengenai price earnings ratio telah banyak dilakukan oleh peneliti sebelumnya. Penelitian yang dilakukan oleh (Sijabat \& Suarjaya, 2018) dan (Susanto \& Marhamah, 2018) menunjukkan bahwa dividend payout ratio berpengaruh terhadap price earnings ratio. Sedangan penelitian yang dilakukan oleh (Mulyani, 2017), (Sijabat \& Suarjaya, 2018), dan (Susanto \& Marhamah, 2018) menunjukkan bahwa debt to equity ratio berpengaruh terhadap price earnings ratio. 
Berdasarkan fenomena dan hasil penelitian terdahulu yang tidak sejalan maka penulis tertarik untuk menguji kembali "pengaruh dividend payout ratio dan debt to equity ratio terhadap price earnings ratio (studi empiris pada perusahaan sektor property real estate and building constructions yang terdaftar di bursa efek indonesia tahun 2016-2018)".

Signalling theory atau teori sinyal dikembangkan oleh (Ross, 1977) menyatakan bahwa pihak eksekutif perusahaan memiliki informasi lebih baik mengenai perusahaannya akan terdorong untuk menyampaikan informasi tersebut kepada calon investor agar harga saham perusahaannya meningkat. Alasan yang mengharuskan perusahaan untuk menyampaikan informasi kepada pihak diluar perusahaan adalah karena adanya asimetri informasi. Hal tersebut terjadi karena yang lebih banyak mengetahui informasi tentang kondisi perusahaan saat ini adalah pihak manajer perusahaan. Sedangkan pihak diluar perusahaan tidak mendapatkan informasi yang cukup mengenai kondisi perusahaan karena tidak terlibat langsung dalam menjalankan operasional perusahaan. Oleh sebab itu, untuk mengurangi adanya asimetri informasi maka perusahaan dapat memberikan sinyal berupa informasi kinerja perusahaan kepada pihak diluar perusahaan.

Keterkaitan signalling theory terhadap price earnings ratio yaitu apabila nilai dari price earnings ratio meningkat, menunjukkan bahwa perusahaan memiliki prospek pertumbuhan yang baik di masa mendatang, sehingga pasar menghargai kinerja perusahaan tersebut dengan memberikan harga yang tinggi dari setiap rupiah laba yang dapat dihasilkan oleh perusahaan. Hal tersebut dapat dijadikan suatu sinyal positif yang digunakan oleh pihak perusahaan untuk menarik minat investor dalam berinvestasi.

Price earnings ratio atau yang disebut dengan rasio harga terhadap pendapatan merupakan ukuran yang digunakan oleh investor untuk melihat bagaimana pasar menghargai kinerja perusahaan yang tercermin dari nilai laba per sahamnya. Menurut (Fahmi, 2017) price earnings ratio adalah perbandingan antara market price per share dengan earning per share dimana bagi para investor semakin tinggi price earnings ratio maka pertumbuhan laba yang diharapkan juga akan mengalami kenaikan. Adapun rumus untuk menghitung price earnings ratio adalah sebagai berikut:

$$
\text { PER }=\frac{\text { Market Per Share }}{\text { Earning Per Share }}
$$

Sumber: (Fahmi, 2017)

Dividend payout ratio merupakan salah satu jenis rasio pasar dimana sudut pandang dari rasio ini lebih banyak berdasarkan pada sudut pandang investor, meskipun pihak manajer juga berkepentingan terhadap rasio-rasio ini. Menurut (Hanafi \& Halim, 2016) dividend payout ratio merupakan rasio yang melihat bagian earning (pendapatan) yang dibayarkan sebagai dividen kepada investor. Adapun rumus untuk menghitung dividend payout ratio adalah sebagai berikut: 


$$
\text { Dividend Payout Ratio }=\frac{\text { Dividend Per: Share }}{\text { Earning Per: Share }}
$$

Sumber: (Fahmi, 2017)

Debt to equity ratio merupakan ukuran yang digunakan untuk melihat besarnya proporsi struktur modal yang digunakan oleh perusahaan. Menurut (Harahap, 2015) debt to equity ratio adalah rasio yang menggambarkan sampai sejauh mana modal pemilik dapat menutupi utang-utang kepada pihak luar dengan kemampuan perusahaan yang digambarkan oleh modal. Adapun rumus untuk menghitung debt to equity ratio adalah sebagai berikut:

$$
D E R=\frac{\text { Total Liabilities }}{\text { Total Shareholders Equity }}
$$

Sumber: (Fahmi, 2017)

Kebijakan dividen merupakan kebijakan yang ditetapkan oleh manajemen perusahaan mengenai laba yang diperoleh perusahaan apakah akan dibagikan kepada investor dalam bentuk dividen atau menahan laba tersebut untuk kebutuhan investasi dan pengembangan usaha pada perusahaan dimasa mendatang.

Perusahaan yang membagikan laba usaha dalam bentuk dividen yang tinggi dan meningkat lebih disukai oleh investor. Oleh karena itu, perusahaan yang mengumumkan informasi mengenai laba yang dibagikan dalam bentuk dividen yang tinggi dan meningkat akan direspon oleh investor sebagai sinyal positif. Karena hal tersebut mencerminkan adanya tanggung jawab dan timbal balik yang tinggi atas dana yang di investasikan oleh investor pada perusahaan berupa membagikan dividen yang tinggi dan meningkat. Sehingga return yang diperoleh investor bukan hanya dari capital gain tetapi juga dari dividen atas saham yang dimilikinya. Dengan demikian, hal ini akan menarik banyak investor untuk menginvestasikan dananya pada perusahaan. Selanjutnya saham perusahaan akan mengalami kenaikan, maka ketika harga saham mengalami kenaikan nilai price earning ratio juga akan mengalami perubahan. Investor tertarik membeli saham perusahaan meskipun dengan harga yang semakin tinggi, namun hal tersebut sebanding dengan return yang akan diperoleh investor.

Hal ini didukung oleh penelitian (Sijabat \& Suarjaya, 2018) dan (Susanto \& Marhamah, 2018) yang menunjukkan bahwa dividend payout ratio berpengaruh terhadap price earnings ratio. Berdasarkan penjelasan tersebut hipotesis penelitian ini adalah:

$\mathrm{H} 1$ = dividend payout ratio berpengaruh terhadap price earnings ratio. Pengaruh debt to equity ratio terhadap price earnings ratio. 
Pengukur suatu kinerja keuangan untuk melihat besarnya proporsi utang yang digunakan perusahaan adalah debt to equity ratio. debt to equity ratio merupakan rasio solvabilitas untuk mengukur besarnya proporsi utang terhadap modal yang dimiliki perusahaan. Rasio ini menunjukkan besaran rupiah modal sendiri yang dijadikan jaminan untuk membayar utang kepada kreditor. Penggunaan utang tidak selalu berdampak buruk bagi perusahaan karena utang yang digunakan untuk membiayai tujuan produktif perusahaan dapat memberikan manfaat berupa tambahan keuntungan yang lebih besar di masa mendatang apabila perusahaan mampu mengelolanya dengan benar. Tetapi disisi lain penggunaan utang yang terlalu tinggi juga tidak baik dikarenakan risiko keuangan yang ditimbulkan semakin tinggi. Apabila perusahaan lebih banyak menggunakan utang dibandingkan dengan modal sendiri maka beban tetap yang ditanggung perusahaan semakin tinggi, akibatnya laba bersih yang dihasilkan semakin rendah karena perusahaan harus membayar pokok utang beserta beban bunga yang timbul akibat penggunaan utang tersebut.

Semakin besar debt to equity ratio artinya perusahaan lebih banyak didanai oleh utang dalam struktur permodalannya. Hal ini akan menurunkan tingkat solvabilitas perusahaan karena adanya kemungkinan perusahaan tidak mampu memenuhi kewajibannya apabila tidak diimbangi dengan keuntungan yang didapat dari hasil penggunaan utang tersebut. Akibatnya kepercayaan investor rendah terhadap kinerja perusahaan karena dianggap sebagai suatu sinyal negatif. Jika sahamnya tidak diminati oleh investor maka penurunan harga saham dapat terjadi sehingga akan berdampak pada price earnings ratio dikarenakan investor cenderung menghindari melakukan investasi pada perusahaan dengan risiko tinggi.

Hal ini didukung oleh penelitian (Mulyani, 2017), (Sijabat \& Suarjaya, 2018) dan (Susanto \& Marhamah, 2018) yang menunjukkan bahwa debt to equity ratio berpengaruh terhadap price earnings ratio. Berdasarkan penjelasan tersebut hipotesis penelitian ini adalah:

$\mathrm{H} 1$ = debt to equity ratio berpengaruh terhadap price earnings ratio.

Berdasarkan perumusan hipotesis diatas, maka kerangka pemikiran dapat dibuat sebagai berikut :

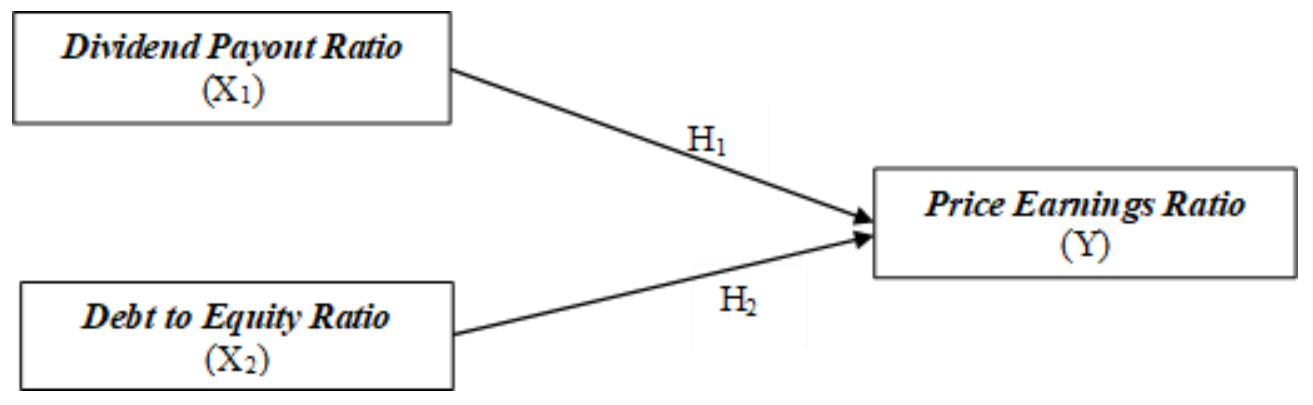

\section{Metode Penelitian}

Penelitian ini menggunakan penelitian dasar atau basic research. Tujuan utama penelitian dasar adalah untuk menghasilkan lebih banyak pengetahuan dan pemahaman 
terhadap fenomena ketertarikan dan membangun teori-teori berdasarkan hasil penelitian. Sedangkan jenis riset berdasarkan studi menggunakan studi kausal yakni studi yang digunakan untuk menguji apakah satu variabel menyebabkan variabel yang lain berubah atau tidak.

Populasi yang digunakan dalam penelitian ini adalah seluruh perusahaan sektor property real estate and building contructions yang terdaftar di bursa efek indonesia (BEI) pada tahun 2016-2018. Berdasarkan proses penentuan sampel, maka perusahaan yang memenuhi kriteria dalam penelitian ini berjumlah 20 perusahaan. Penelitian ini menggunakan 3 tahun pengamatan yaitu tahun 2016-2018, sehingga jumlah seluruh sampel yang akan digunakan dalam penelitian ini adalah sebanyak 60 sampel.

Teknik pengumpulan data pada penelitian ini menggunakan sumber data sekunder. Data sekunder diperoleh dari laporan tahunan dan ringkasan laporan kinerja perusahaan sektor property real estate and building constructions yang terdaftar di bursa efek indonesia tahun 2016- 2018 melalui situs www.idx.co.id.

\section{Hasil dan Pembahasan}

\section{A. Hasil Penelitian}

\section{Hasil Statistik Deskriptif}

Analisis statistik deskriptif digunakan untuk memperoleh gambaran umum sampel data. Berikut ini adalah hasil dari statistik deskriptif:

Tabel 2

Descriptive Statistics

\begin{tabular}{cccc}
\hline & $\mathrm{N}$ & Mean & $\begin{array}{c}\text { Std. } \\
\text { Deviation }\end{array}$ \\
\hline PER & 60 & 16,9596 & 13,44694 \\
\hline DPR & 60 &, 3064 &, 40032 \\
\hline DER & 60 & 1,0648 &, 84539 \\
\hline Valid N (listwise) & 60 & &
\end{tabular}

Berdasarkan tabel 2 dapat diketahui variabel price earnings ratio memiliki nilai rata-rata (mean) sebesar 16,9596 dengan nilai standar deviasi sebesar 13,44694. Nilai rata-rata (mean) memiliki nilai yang lebih besar dibandingkan dengan nilai standar deviasi yaitu 16,9596 > 13,44694 artinya sampel yang dimiliki besarnya hampir sama antar masing- masing sampel (data tidak variatif).

Variabel dividend payout ratio memiliki nilai rata-rata (mean) sebesar 0,3064 dengan nilai standar deviasi sebesar 0,40032. Nilai rata-rata (mean) memiliki nilai yang lebih kecil dibandingkan dengan nilai standar deviasi yaitu 0,3064 $<0,40032$ artinya sampel memiliki perbedaan data yang relatif besar (data variatif).

Variabel debt to equity ratio memiliki nilai rata-rata (mean) sebesar 1,0648 dengan nilai standar deviasi sebesar 0,84539. Nilai rata-rata (mean) 
memiliki nilai yang lebih besar dibandingkan dengan nilai standar deviasi yaitu 1,0648 > 0,84539 artinya sampel yang dimiliki besarnya hampir sama antar masing-masing sampel perusahaan (data tidak variatif).

\section{Hasil Uji Asumsi Klasik}

1) Uji Normalitas

Uji normalitas bertujuan untuk menguji apakah dalam model regresi, variabel pengganggu atau residual memiliki distribusi normal. Model regresi yang baik adalah memiliki distribusi normal atau mendekati normal. Berikut ini adalah hasil uji normalitas:

Table 3

One-Sample Kolmogorov-Smirnov Test

\begin{tabular}{|c|c|c|}
\hline \multicolumn{3}{|c|}{ Unstandardized Residual } \\
\hline $\mathrm{N}$ & & 60 \\
\hline \multirow{2}{*}{$\begin{array}{l}\text { Normal } \\
\text { Parameters }\end{array}$} & Mean &, 0000000 \\
\hline & Std. Deviation & 12,38098418 \\
\hline \multirow{3}{*}{$\begin{array}{l}\text { Most Extreme } \\
\text { Differences }\end{array}$} & Absolute &, 121 \\
\hline & Positive &, 121 \\
\hline & Negative &,- 071 \\
\hline \multicolumn{2}{|l|}{ Test Statistic } &, 121 \\
\hline \multicolumn{2}{|c|}{ Asymp. Sig. (2-tailed) } &, $029^{c}$ \\
\hline \multicolumn{3}{|c|}{ a. Test distribution is Normal. } \\
\hline \multicolumn{3}{|c|}{ b. Calculated from data. } \\
\hline \multicolumn{3}{|c|}{ c. Lilliefors Significance Correction. } \\
\hline \multicolumn{3}{|c|}{ Sumber: Output SPSS 25, 2020} \\
\hline
\end{tabular}

Berdasarkan hasil uji normalitas pada tabel dapat dilihat bahwa nilai nilai assym. Sig. (2-tailed) adalah sebesar 0,029. Nilai signifikansi 0,029 lebih kecil daripada tingkat signifikan 0,05 maka dapat disimpulkan data dalam penelitian ini memiliki distribusi yang tidak normal.

Untuk mengatasinya, peneliti melakukan pengujian ulang dengan mengetahui terlebih dahulu bagaimana bentuk grafik histogramnya. Bentuk grafik histogram pada variabel menunjukkan moderate positive skewness sehingga mentransformasi datanya harus dirubah menggunakan transformasi data $S Q R T$ pada semua variabel. Berikut ini hasil pengujian setelah dilakukan transformasi data ditunjukkan sebagai berikut:

Table 4

One-Sample Kolmogorov-Smirnov Test

\begin{tabular}{llr}
\hline & & Unstandardized Residual \\
\hline $\mathrm{N}$ & & 60 \\
\hline Normal & Mean &, 0000000 \\
\cline { 2 - 3 } Parameters $^{\mathrm{a}, \mathrm{b}}$ & Std. Deviation & 1,47901597 \\
\hline Most Extreme & Absolute &, 092 \\
\cline { 2 - 3 } Differences & Positive &, 092 \\
\hline & Negative &,- 080 \\
\hline Test Statistic & &, 092 \\
\hline
\end{tabular}




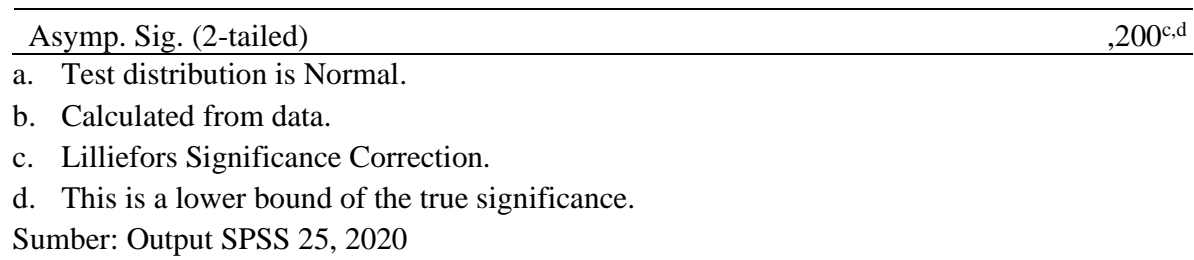

Hasil pengujian ulang pada tabel dapat dilihat bahwa nilai asymp. Sig. (2-tailed) adalah sebesar 0,200. Karena nilai signifikan sebesar 0,200 lebih besar dibandingkan tingkat signifikan 0,05 maka dapat disimpulkan bahwa data penelitian telah terdistribusi normal.

2) Hasil Uji Multikolinearitas

Uji multikolinearitas bertujuan untuk menguji apakah model regresi ditemukan adanya korelasi antar variabel bebas (independen). Untuk mendeteksi ada atau tidaknya multikolinearitas di dalam model regresi yaitu jika nilai tolerance 0,10 atau sama dengan VIF 10 maka terjadi multikolinearitas antar variabel independen (Ghozali, 2018).

Table 5 Coefficients $^{\mathbf{a}}$

\begin{tabular}{lcc}
\hline & \multicolumn{3}{c}{ Collinearity Statistics } & \\
\cline { 2 - 3 } Model & Tolerance & VIF \\
\hline Constant) & & 1,002 \\
\hline DPR &, 998 & 1,002 \\
\hline DER &, 998 & \\
\hline
\end{tabular}

a. Dependent Variable: PER

Sumber: Output SPSS 25, 2020

Berdasarkan tabel dapat diketahui bahwa nilai tolerance variabel dividend payout ratio dan debt to equity ratio adalah sebesar 0,998 lebih besar dari nilai tolerance 0,10 . Sementara itu nilai VIF variabel dividend payout ratio dan debt to equity ratio adalah sebesar 1,002 lebih kecil dari nilai VIF 10,00. Sehingga dapat disimpulkan tidak terjadi multikolinearitas.

3) Hasil Uji Autokorelasi

Uji autokorelasi bertujuan untuk menguji apakah dalam model regresi linear ada korelasi antara kesalahan pengganggu pada periode $t$ dengan kesalahan pengganggu pada periode t-1 (periode sebelumnya). Berikut ini adalah hasil uji autokorelasi Durbin Watson:

Tabel 6

Model Summary ${ }^{\mathrm{b}}$

\begin{tabular}{lllll}
\hline & \multicolumn{2}{c}{ Adjusted R } & & \\
Sodel & Square & & Durbin-Watson & \\
\hline 1 & &, 039 & & 2,120 \\
\hline
\end{tabular}

a. Predictors: (Constant), DER, DPR

b. Dependent Variable: PER

Sumber: Output SPSS 25, 2020 
Berdasarkan tabel 6, nilai durbin-watson sebesar 2,120 dengan banyaknya data $(\mathrm{n}=60)$ dan jumlah variabel independen $(\mathrm{k}=2)$, maka akan diperoleh data sebagai berikut:

Tabel 7

Durbin Watson

\begin{tabular}{ccc}
\hline $\mathrm{N}$ & \multicolumn{3}{c}{$\mathrm{k}=2$} \\
\cline { 2 - 3 } & $\mathrm{dL}$ & $\mathrm{dU}$ \\
\hline 60 & 1,5144 & 1,6518 \\
\hline
\end{tabular}

Dapat dilihat bahwa nilai dL sebesar 1,51421 dan dU sebesar 1,6518 maka nilai 4-dU adalah sebesar 2,3482 (4-1,6518). Nilai durbin watson tersebut telah berada diantara nilai dU dan 4-dU $(1,6518<2,120<2,3482)$. Maka dapat disimpulkan bahwa tidak terdapat masalah autokorelasi.

4) Uji Heteroskedastisitas

Uji heteroskedastisitas bertujuan untuk menguji apakah dalam model regresi terjadi ketidaksamaan variance dari residual satu pengamatan ke pengamatan lain. Uji heteroskedastisitas yang digunakan dalam penelitian ini adalah uji glejser yang dilakukan dengan cara meregresikan antara variabel independen dengan nilai absolut residual. Berikut ini adalah hasil dari uji heteroskedastisitas:

Tabel 8

Coefficients $^{\mathrm{a}}$

\begin{tabular}{rrrr} 
Model & \multicolumn{2}{c}{ T } & Sig. \\
\hline 1 & (Constant) &, 953 &, 344 \\
\hline DPR & 1,813 &, 075 \\
\hline DER & 1,726 &, 090 \\
\hline
\end{tabular}

a. Dependent Variable: ABS_Res2

Sumber: Output SPSS 25, 2020

Berdasarkan tabel 8, dapat dilihat bahwa nilai signifikan variabel dividend payout ratio sebesar 0,075 dan debt to equity ratio sebesar 0,090 lebih besar dari tingkat signifikan 0,05. Berdasarkan hasil pengujian tersebut maka dapat disimpulkan tidak terdapat gejala heteroskedastisitas pada model regresi.

5) Hasil Analisis Regresi Linear Berganda

Penelitian ini dianalisis dengan model regresi linear berganda untuk melihat ada tidaknya pengaruh dari variabel independen dividend payout ratio dan debt to equity ratio terhadap variabel dependen price earnings ratio. Berikut ini tabel hasil analisis regresi linear berganda: 
Tabel 9

Coefficients $^{\mathrm{a}}$

\begin{tabular}{lllr}
\hline & & \multicolumn{3}{c}{ Unstandardized Coefficients } \\
\cline { 3 - 5 } Model & & B & \multicolumn{2}{c}{ Std. Error } \\
\cline { 3 - 5 } & & 3,164 &, 619 \\
\hline 1 & DPR & 1,439 &, 689 \\
\hline & DER &,- 024 &, 495 \\
\hline a. & $\begin{array}{l}\text { Dependent Variable: PER } \\
\text { Sumber: Output SPSS 25, 2020 }\end{array}$ & &
\end{tabular}

Berdasarkan hasil analisis regresi yang disajikan pada tabel, maka dapat dibuat persamaan regresi linear berganda sebagai berikut:

$$
\text { PER }=3,164+1,439 \text { DPR }-0,024 \text { DER + e }
$$

Penjelasan dari persamaan regresi linear berganda adalah sebagai berikut:

1. Berdasarkan persamaan tersebut, nilai konstanta sebesar 3,164 menyatakan apabila nilai dividend payout ratio (X1) dan debt to equity ratio (X2) bernilai konstan atau sama dengan nol maka nilai price earnings ratio $(\mathrm{Y})$ sebesar 3,164.

2. Nilai koefisien regresi variabel dividend payout ratio $\left(\mathrm{X}_{1}\right)$ sebesar 1,439 menunjukkan bahwa setiap kenaikan dividend payout ratio sebesar 1 satuan maka price earnings ratio (Y) akan mengalami kenaikan sebesar 1,439 dengan asumsi semua variabel independen yang digunakan dalam penelitian ini bernilai konstan atau sama dengan nol.

3. Nilai koefisien regresi variable debt to equity ratio $\left(\mathrm{X}_{2}\right)$ sebesar $-0,024$ menunjukkan bahwa setiap peningkatan debt to equity ratio sebesar 1 satuan maka price earnings ratio (Y) akan mengalami penurunan sebesar 0,024 dengan asumsi semua variabel independen yang digunakan dalam penelitian ini bernilai konstan atau sama dengan nol.

6) Hasil Uji Hipotesis (Uji t)

Pengujian ini dilakukan untuk mengetahui ada atau tidaknya pengaruh secara parsial (individual) variabel dividend payout ratio dan debt to equity ratio terhadap price earnings ratio. Berikut ini tabel hasil analisis dari uji t:

\section{Tabel 10}

Coefficients $^{\mathrm{a}}$

\begin{tabular}{ccc} 
Model & $\mathrm{T}$ & Sig. \\
\hline (Constant) & 5,112 &, 000 \\
\hline DPR & 2,089 &, 041 \\
\hline DER &,- 048 &, 962 \\
\hline
\end{tabular}

a. Dependent Variable: PER 
Berdasarkan hasil pengujian hipotesis pada tabel tersebut dapat dilihat bahwa variabel dividend payout ratio memiliki p-value atau nilai signifikansi sebesar 0,041 $<0,05$ yang berarti $\mathrm{H}_{\mathrm{a}}$ diterima. Artinya hipotesis pertama yaitu dividend payout ratio berpengaruh terhadap rice earnings ratio.

Berdasarkan hasil pengujian hipotesis pada tabel tersebut dapat dilihat bahwa variabel debt to equity ratio memiliki p-value atau nilai signifikansi sebesar 0,962 > 0,05 yang berarti $\mathrm{H}_{\mathrm{a}}$ ditolak. Artinya hipotesis kedua yaitu debt to equity ratio tidak berpengaruh terhadap price earnings ratio.

7) Hasil Uji Koefisien Determinasi

Koefisien determinasi (R2) digunakan untuk mengukur seberapa jauh kemampuan model dalam menerangkan variabel dependen dengan melihat nilai adjusted $r$ - square. Hasil uji koefisien determinasi adalah sebagai berikut:

\section{Tabel 11}

Model Summary ${ }^{\mathrm{b}}$

\begin{tabular}{cccc}
\hline Model & $\mathrm{R}$ & R Square & $\begin{array}{c}\text { Adjusted R } \\
\text { Square }\end{array}$ \\
\hline 1 &, $267^{\mathrm{a}}$ &, 071 &, 039 \\
\hline
\end{tabular}

a. Predictors: (Constant), DER, DPR

b. Dependent Variable: PER

Sumber: Output SPSS 25, 2020

Berdasarkan tabel 11, dapat dilihat nilai adjusted $r$-square adalah sebesar 0,039. Hasil tersebut menunjukkan bahwa kemampuan variabel independen dalam menjelaskan variabel dependen cukup rendah, yaitu hanya sebesar 3,9\% sedangkan sisanya $96,1 \%$ dijelaskan oleh variabel independen lain yang tidak dimasukkan dalam penelitian.

\section{B. Pembahasan}

\section{Pengaruh Dividend Payout Ratio Terhadap Price Earnings Ratio}

Berdasarkan hasil uji hipotesis pada tabel, dividend payout ratio memiliki nilai signifikansi sebesar 0,041 < 0,05 dengan koefisien regresi sebesar 1,439. Berdasarkan hasil tersebut dapat disimpulkan bahwa dividend payout ratio memiliki pengaruh terhadap price earnings ratio, sehingga hipotesis pertama $\left(\mathrm{H}_{1}\right)$ dalam penelitian ini diterima. Hasil koefisien regresi yang bernilai positif menunjukkan terdapat hubungan yang searah antara dividend payout ratio dan price earnings ratio, di mana peningkatan dividend payout ratio akan menyebabkan price earnings ratio ikut meningkat begitupun sebaliknya apabila dividend payout ratio mengalami penurunan maka price earnings ratio akan menurun.

Hasil penelitian ini sejalan dengan penelitian yang telah dilakukan oleh (Sijabat \& Suarjaya, 2018) dan (Susanto \& Marhamah, 2018) yang 
menemukan bukti bahwa dividend Payout ratio berpengaruh terhadap price earnings ratio. Namun hasil penelitian ini tidak sejalan dengan penelitian yang telah dilakukan oleh (Utomo, Andini, \& Raharjo, 2016) yang menunjukkan bahwa dividend payout ratio tidak berpengaruh terhadap price earnings ratio.

Dividend payout ratio merupakan salah satu rasio yang menunjukkan persentase setiap keuntungan yang diperoleh yang didistribusikan kepada pemegang saham dalam bentuk uang tunai. Meningkatnya presentase dividend payout ratio menunjukkan bahwa perusahaan memiliki kemampuan yang baik dalam menghasilkan laba. Berdasarkan data yang didapat selama tahun pengamatan, Rasio dividend payout ratio pada sebagian besar perusahaan tercatat mengalami tren yang cenderung meningkat. Meningkatnya dividend payout ratio dapat terjadi karena perusahaan mampu mengelola laba bersih perusahaan dengan baik. Selain itu, alasan lain yang menyebabkan dividend payout ratio mengalami kenaikan adalah karena perolehan laba bersih yang diterima perusahaan stabil. Besar kecilnya presentase dividend payout ratio ini dapat menjadi bahan pertimbangan investor untuk memutuskan apakah saham tersebut layak dimasukkan dalam portofolio investasi atau tidak.

Berkaitan dengan signalling theory, informasi berupa peningkatan dan penurunan dividend payout ratio dapat dijadikan sebagai suatu sinyal oleh pihak perusahaan untuk menggambarkan kondisi perusahaan saat ini yang ditujukan kepada pihak investor dalam pengambilan keputusan investasi agar harga sahamnya meningkat. Pada penelitian ini diperoleh hasil yang menunjukkan bahwa dividend payout ratio selama tahun pengamatan mengalami peningkatan. Peningkatan dividend payout ratio menunjukkan bahwa perusahaan mampu memaksimalkan keuntungan yang didapat dengan menggunakan sumber pendanaan yang berasal dari pemilik modal. Investor dapat menggunakan informasi ini sebagai bahan pertimbangan apakah saham tersebut layak dikoleksi atau tidak. Tingkat permintaan dan penawaran terhadap suatu saham dapat menyebabkan harga sahamnya mengalami perubahan. Harga saham merupakan indikator penting yang digunakan untuk menentukan nilai price earnings ratio, oleh sebab itu setiap perubahan harga yang terjadi dapat mempengaruhi besar kecilnya nilai price earnings ratio.

\section{Pengaruh Debt to Equity Ratio Terhadap Price Earnings Ratio.}

Berdasarkan hasil uji hipotesis pada tabel, variabel debt to equity ratio memiliki nilai signifikansi sebesar 0,962>0,05 dengan koefisien regresi sebesar -0,024. Berdasarkan hasil tersebut dapat disimpulkan bahwa debt to equity ratio tidak memiliki pengaruh terhadap price earnings ratio, sehingga hipotesis kedua $\left(\mathrm{H}_{2}\right)$ dalam penelitian ini ditolak.

Hasil ini sejalan dengan penelitian yang telah dilakukan oleh (Sudaryanti \& Sahroni, 2016) dan (Utomo et al., 2016) yang menemukan bukti bahwa debt to equity ratio tidak berpengaruh terhadap price earnings ratio. Namun hasil penelitian ini tidak sejalan dengan penelitian yang telah dilakukan oleh 
(Mulyani, 2017), (Sijabat \& Suarjaya, 2018) dan (Susanto \& Marhamah, 2018) yang menunjukkan bahwa debt to equity ratio berpengaruh terhadap price earnings ratio.

Hasil penelitian ini menyatakan bahwa debt to equity ratio tidak berpengaruh terhadap price earnings ratio, hal ini disebabkan karena karakteristik data riset yang menunjukkan bahwa porsi DER untuk seluruh perusahaan sampel selama periode riset relatif sama antara satu dengan lainnya. Hal ini dibuktikan melalui statistik deskriptif dengan menggunakan informasi nilai mean dan deviasi standar. Variabel DER mempunyai mean sebesar 1,064 dan deviasi standar sebesar 0,84539. Jika dilihat dari tingkat variasi data riset dengan membandingkan dua informasi tersebut, maka diperoleh angka sebesar 0,7939. Angka tersebut kurang dari satu atau menunjukkan bahwa data riset tidak variatif, yang artinya DER untuk seluruh perusahaan sampel selama periode riset mempunyai tingkatan yang serupa sehingga menjadi tidak relevan jika digunakan dalam pengambilan keputusan investasi yang nantinya akan tercermin melalui PER.

Berdasarkan data yang didapat selama periode penelitian ini bersifat riil karena berasal dari data yang digunakan dalam riset, bukan bersifat dugaan semata. Berkaitan dengan signalling theory, perusahaan yang mengurangi utangnya dan lebih banyak memanfaatkan modal sendiri dalam membiayai aktivitas perusahaannya dianggap sebagai suatu sinyal positif bagi investor. Hal ini disebabkan karena penggunaan utang akan mempengaruhi besar kecilnya tingkat pengembalian yang akan diterima pemegang saham karena perusahaan lebih memfokuskan pada pelunasan pokok utang beserta bunga yang timbul. Selain itu penggunaan utang yang rendah mengakibatkan risiko kebangkrutan perusahaan relatif rendah. Adanya risiko yang sangat rendah yang dapat menyebabkan investasi pada saham tersebut kurang menarik sehingga investor enggan membeli saham tersebut. Oleh karena itu, tinggi rendahnya debt to equity ratio perusahaan tidak berpengaruh terhadap kenaikan price earnings ratio.

\section{Kesimpulan}

Berdasarkan hasil penelitian dan pembahasan pada bab sebelumnya, maka dapat ditarik kesimpulan sebagai berikut: 1) Dividend payout ratio berpengaruh terhadap price earnings ratio. 2) Debt to equity ratio tidak berpengaruh terhadap price earnings ratio. 


\section{BIBLIOGRAFI}

Fahmi, Irham. (2017). Analisis Laporan Keuangan. Bandung:. CV. Alfabeta

Ghozali, Imam. (2018). Aplikasi analisis multivariete dengan program IBM SPSS 23.

Hanafi, Mamduh M., \& Halim, Abdul. (2016). Analisis Laporan Keuangan, Edisi Ketiga. Yogyakarta: Upp Stim Ykpn.

Harahap, Syafri Sofyan. (2015). Analisis Kritis atas Laporan Keuangan, Cetakan Kedua belas. Jakarta: PT. Raja Grafindo Persada.

Mulyani, Pitaloka. (2017). Pengaruh Return on Equity, Earning per Share (EPS), dan Debt to Equity Ratio terhadap Price Earning Ratio (PER) Pada PT Indofood Sukses Makmur. Tbk Periode 2012-2014. Widyakala: Journal Of Pembangunan Jaya University, 4(1), 52-59.

Ross, Stephen A. (1977). The determination of financial structure: the incentivesignalling approach. The Bell Journal of Economics, 23-40.

Rusliati, Ellen, \& Farida, Esti Nur. (2010). Pemecahan saham terhadap likuiditas dan return saham. Jurnal Bisnis dan Akuntansi, 12(3), 161-174.

Safitri, Abied Luthfi. (2013). Pengaruh Earning Per Share, Price Earning Ratio, Return On Asset, Debt To Equity Ratio dan Market Value Added terhadap Harga Saham dalam kelompok Jakarta Islamic Index tahun 2008-2011. Universitas Negeri Semarang.

Sijabat, Frengky David, \& Suarjaya, Anak Agung Gede. (2018). Pengaruh DPR, DER, ROA Dan ROE Terhadap Price Earning Ratio Pada Perusahaan Manufaktur. EJurnal Manajemen, 7(7), 3681-3708.

Simadibrata, Theresia Adelia. (2012). Peranan good corporate governance terhadap kualitas pelaporan keuangan dan kepercayaan investor. Widya Mandala Catholic University Surabaya.

Sudaryanti, Dedeh Sri, \& Sahroni, Nana. (2016). Pengaruh Return On Equity (Roe) Dan Debt To Equity Ratio (Der) Terhadap Price Earning Ratio (Per)(Studi Empiris Pada Pt. Holcim Indonesia Tbk.). Jurnal Ekonomi Manajemen, 2(1), 40-47.

Sudirman, Sudirman, \& Alhudhori, M. (2018). Pengaruh Konsumsi Rumah Tangga, Investasi Terhadap Pertumbuhan Ekonomi di Provinsi Jambi. Ekonomis: Journal of Economics and Business, 2(1), 81-91.

Susanto, Edi, \& Marhamah, Marhamah. (2018). Pengaruh Current Ratio, Debt Equity Ratio, Devidend Payout Ratio, Ukuran Perusahaan, Price Book Value, Earning Per Share, Return On Asset, Dan Operating Profit Terhadap Price Earning Ratio (Studi Empiris Pada Perusahaan Manufaktur Yang Terdaftar Di Bei Ta. JAB (Jurnal 
Janiman

Akuntansi \& Bisnis), 4(02).

Tambunan, Andy Porman. (2008). Menilai Harga Wajar Saham. Elex Media Komputindo.

Utomo, Wawan, Andini, Rita, \& Raharjo, Kharis. (2016). Pengaruh Leverage (DER), Price Book Value (PBV), Ukuran Perusahaan (Size), Return On Equity (ROE), Deviden Payout Ratio (DPR) dan Likuiditas (Cr) terhadap Price Earning Ratio (Per) pada Perusahaan Manufaktur yang Listing di BEI Tahun 2009-2014. Journal of Accounting, 2(2). 